\title{
DOCE CUENTOS PEREGRINOS O EL ESPACIO DE LA PÉRDIDA: GABRIEL GARCÍA MÁRQUEZ EN EL LABERINTO EUROPEO
}

\author{
Mercedes CANO PÉREZ
}

Universidad de Alicante

\section{RESUMEN}

En Doce cuentos peregrinos (1992) Gabriel García Márquez atraca en territorio europeo para dejar allí en calidad de náufragos a sus protagonistas, latinoamericanos que vagan por un continente lejano en todos los sentidos. El presente artículo pretende analizar los mecanismos constructivos de la espacialidad europea y americana (la primera como vivida, la segunda como rememoración nostálgica) en estos doce relatos. Al salir del ámbito cerrado y perfecto de Macondo, el escritor colombiano accede al reto de llevarse a sus criaturas a un entorno urbano, cambiante, capaz de traicionar su visión del mundo y su lógica vital; de esta manera se presenta lo europeo en las narraciones, como si la función de las antiguas crónicas de Indias se hubiera invertido y ahora los cronistas fuesen los americanos, deslumbrados hasta lo más profundo por la extrañeza y salvajismo racionalista de Europa. Más allá de una concepción tradicional del espacio (como marco pasivo de la trama) García Márquez utiliza el concepto en su acepción más polisémica y abierta, de manera que lo espacial marca también fronteras abstractas entre el personaje y los demás, es una ventana para bucear en la subjetividad de los protagonistas o se llena en ocasiones de valores alegóricos y simbólicos que remarcan la dicotomía evidente de la que beben todas las narraciones: el enfrentamiento entre América y Europa. En total, destacamos siete valores semánticos vinculados a la espacialidad en los relatos: el uso de la itinerancia como base constructiva de las historias, la superstición en contraste con la fría racionalidad europea, las ciudades como prefiguraciones de la muerte, el viaje religioso (o peregrinaje en sentido estricto), la construcción topográfica de la infancia, la caracterización de un espacio kafkiano, aniquilador del individuo, y el advenimiento de lo maravilloso vinculado siempre a la presencia de lo latinoamericano. Tras el análisis de estos 
conceptos en función de los relatos en los que aparecen, nos detendremos finalmente la última historia del conjunto, «El rastro de tu sangre en la nieve», donde a la estética gélida e invernal de la trama, se añade el hálito de los fantásticos cuentos de hadas, eso sí, con un final trágico.

Palabras clave: narrativa hispanoamericana, Gabriel García Márquez, relatos, Doce cuentos peregrinos, espacialidad, significado, Europa, superstición, muerte, conflicto, topografía, espacio urbano, viaje, racionalidad, infancia, espacio kafkiano, cuentos de hadas, crónica de Indias.

\section{ABSTRACT}

In Twelve pilgrims tales (1992), García Márquez leads us to European soil in order to present his main characters as shipwrecked, Latin American people who are wandering about in a strange continent. This article analyzes the constructive mechanisms of European and American spatiality (the first, as a space lived currently, and the second as a nostalgic remembrance) in these twelve stories. Leaving the area closed and perfect of Macondo, the Colombian writer agrees to the challenge to bring their creatures to an urban and changing setting, capable of betraying their worldview. In this way it presents European world as if the role of the ancient Indian chronicles had been reversed and now the Americans were chroniclers blinded by the strangeness and wildness of Europe. Beyond a traditional conception of space (passive part of the plot), García Márquez uses the concept in its most polysemic meaning; so space also marks abstract borders between the character and the others, it is a way to dive in the subjectivity of the main characters and sometimes it is full with allegorical and symbolic values that emphasize the dichotomy of the twelve stories: the confrontation between America and Europe. To sum up, we highlight seven semantic values associated with spatiality in Twelve pilgrims tales: the use of itinerancy in the construction of the stories, superstition (in contrast to the cold European rationality), cities as foreshadowings of death, the religious journey (or pilgrimage), the building of childhood, Kafkaesque space (which destroys the individual) and the providential arrival of wonder, forever linked to the presence of Latin American characters. Finally we will analyze the last story, «The trail of your blood in the snow», where we find an icy and wintry aesthetics, and also the breath of the great fairy tales but with a tragic end. Key words: Latin American literatura, Gabriel García Márquez, stories, Twelve pilgrims tales, spatiality, meaning, Europe, superstition, death, conflicto, topography, urban space, trip, rationality, childhood, Kafkaesque espace, fairy tales, Indian chronicle.

Con la publicación en 1992 de un singular libro de relatos, Gabriel García Márquez hace su especial contribución al Quinto Centenario del Descubrimiento de América al invertir el papel de los cronistas y describirnos las extrañezas de la lejana Europa desde el punto de vista sorprendido de los americanos. Las 
historias que componen sus Doce cuentos peregrinos hacen gala desde el principio de su condición heterodoxa en cuanto al género, ya que se encuentran entre el relato literario, el guión de cine y la crónica periodística (de ahí el uso abundante del narrador testigo). El prólogo, titulado «Porqué doce, porqué cuentos y porqué peregrinos» [sic], ha sido objeto de diversas interpretaciones, desde quienes lo consideran un texto fiable en el que el autor explica el proceso de escritura de los relatos, hasta otros que consideran que se trata de un texto ficcional como los otros doce, convirtiéndose en el décimo tercer relato del conjunto ${ }^{1}$. Asumiendo lo dicho en este texto prologal como cierto (o al menos con intención de serlo, teniendo en cuenta la habilidad del autor para jugar con los conceptos de verosimilitud y ficción) nos encontramos allí explicitados los pormenores de la creación de los cuentos. Todos partieron de una concepción azarosa: compuestos en un amplio periodo de tiempo y de forma dispersa, ninguno de los relatos convenció al autor de forma definitiva, así que viajaron en un cuaderno escolar, se perdieron y reescribieron, en un «incesante peregrinaje de ida y vuelta al cajón de la basura» (García Márquez, 1992: 18) que termina finalmente en las doce narraciones del volumen. También alude el autor en su prólogo al motivo que le lleva a la composición de los cuentos: es un sueño en el que se ve a sí mismo asistiendo a la magnífica fiesta de su entierro, tras la cual no puede continuar la parranda con los compañeros al descubrir que la muerte es precisamente eso, «no estar nunca más con los amigos» (14). Esta impotencia despierta en García Márquez su ancestral sentimiento de soledad y una total «toma de conciencia» de su identidad como americano, por lo que decide que es «un buen punto de partida para escribir sobre las cosas extrañas que les suceden a los latinoamericanos en Europa» (14).

Aunque se suele destacar que la clave para interpretar los relatos es el prólogo, considero que a tal efecto es mucho más útil revisar el discurso que el escritor pronunció al recibir el premio Nobel y que lleva por título «La soledad de América Latina». En las palabras del colombiano pervive una desazón íntima al contemplar la desunión entre Europa y América, sobre todo porque el prurito racionalista de la primera le impide acceder a la peculiar realidad de lo americano; como consecuencia, «la interpretación de nuestra realidad con esquemas ajenos sólo contribuye a hacernos cada vez más desconocidos, cada

1. Así lo piensa Kristine Vanden Berghe en su artículo «Los doce cuentos de García Márquez. ¿O son trece? Paratopía, parodia e intertextualidad en los Doce cuentos peregrinos», donde defiende la tesis de que el autor construye en total trece relatos y con ello hace una alusión implícita a su admirado William Faulkner, cuya primera colección de cuentos se publicó con el título de These thirteen. 
vez menos libres, cada vez más solitarios» (García Márquez, 2010: 26). Los Doce cuentos peregrinos se convierten entonces en una especie de campo de prueba del malentendido, donde es el espacio europeo el escenario en el que se ejemplificará el contraste eterno entre «nuestra América» (21) y «la Europa venerable» (26), obligadas, pese a todo, a entenderse. De esta manera, el autor vuelve a su gran tema, el de la soledad de América, pero para su tratamiento toma como anclaje y nexo de unión un elemento de la morfología de la narración: el espacio, y en concreto, el espacio urbano europeo que, como veremos, se convertirá en el verdadero eje semántico de la obra.

\section{EL SALTO HACIA EL ESPACIO EUROPEO}

En esta obra García Márquez sale de su referente espacial predilecto, el latinoamericano, para «lanzar» a sus personajes al laberinto europeo. El espacio cerrado y perfecto de Macondo había sido el escenario inseparable de muchas de sus narraciones, hasta el punto de que para Víctor Ivanovici constituía un «espacio ontológico», «una figura mandálica, de círculos concéntricos, progresivamente magnetizados por un poderoso y único núcleo/origen» (Ivanovici, 2007: 88). Pero en los Doce cuentos peregrinos este eje espacial se pierde y diversifica cuando los personajes deben buscar su lugar en la remota y urbana Europa, donde ninguna fuerza los imanta hacia un centro o sentido. El espacio urbano europeo aparece como un discontinuo, como un todo fragmentado en el que los latinoamericanos vagan por Barcelona, Ginebra, Roma, Viena o París intentando (sin fortuna) evitar el caos y el desamparo de la maquinaria racionalista europea. Estas ciudades aparecen siempre dibujadas desde el prisma del latinoamericano, que «peregrina» por ellas a veces contra su voluntad. Hay quienes convienen en que García Márquez idea un imaginario hostil para representar lo europeo, sin embargo primaría más en el autor la construcción literaria de ciudades-espejo en las que los personajes se contemplan a sí mismos en su soledad intrínseca, en su vacío y nostalgia personal. Con idénticos propósitos había trabajado el espacio la llamada novela de la selva, donde el infierno verde se convertía en una jaula mortal para esos seres que caían en las redes de lo desconocido y lo ajeno; los protagonistas de La vorágine (de José Eustasio Rivera) o Desde el río (de Alfredo Leal Cortés) se adentraban en un espacio salvaje, en un silencio que acababa por dejarlos solos ante sus miedos. Los Doce cuentos peregrinos no constituyen una visión totalmente peyorativa de Europa (como la novela de la selva no era un alegato contra el espacio indómito de la naturaleza virgen) sino que se potencia la percepción de aquel no habituado a esos territorios y que los percibe entonces desde la otredad y el aislamiento. En definitiva, el sistema de lugares que cimenta los cuentos de 
García Márquez aparece fuertemente polarizado para ayudarnos a establecer el contraste entre lo europeo y el individuo americano que se halla perdido en los callejones sin salida de lo urbano.

El propio autor confiesa en el prólogo que en cuanto decidió sacar adelante el libro de relatos necesitó volver a Barcelona, Ginebra, Roma y París para «comprobar la fidelidad de mis recuerdos casi veinte años después»; aquí es donde el novelista encuentra la clave que necesitaba:

Ninguna de ellas [las ciudades] tenía ya nada que ver con mis recuerdos. Todas, como la Europa actual, estaban enrarecidas por una inversión asombrosa: los recuerdos reales me parecían fantasmas de la memoria, mientras los recuerdos falsos eran tan convincentes que habían suplantado a la realidad. De modo que me era imposible distinguir la línea divisoria entre la desilusión y la nostalgia. Fue la solución final. Pues por fin había encontrado lo que más me hacía falta para terminar el libro, y que sólo podía dármelo el transcurso de los años: una perspectiva en el tiempo (García Márquez, 1992: 18).

Este punto es fundamental en la lectura que el novelista realiza de la vida urbana europea: en su viaje de retorno percibe una indescriptible sensación de pérdida e irrealidad, y esos son los ingredientes que insufla a sus personajes cuando decide convertirles en seres ajenos, de paso, forzados a contrastar continuamente el espacio que viven con el que recuerdan. Esta comparación siempre será decepcionante pero, como no pueden sustraerse de ella, aprenden a construir un ideal mental del espacio americano que va ennobleciéndose cada vez más en la utopía y haciéndose más abstracto e inasible. El resultado es la sublimación del espacio americano, apreciado sólo porque no se posee, porque se encuentra distante; mientras lo europeo se percibe a retazos, como un caos regido irónicamente por la racionalidad y una disciplina obsoleta que ya no puede regular la fluidez y la espontaneidad de un mundo cambiante.

Desde un punto de vista teórico, el espacio es un elemento fundamental en el orden de lo ficcional. Entre sus valores básicos está es el de constituir la base física de la narración; obviamente en los estudios tradicionales sobre narratología esta función se ha considerado exclusiva y absoluta, hasta el punto de que otros valores añadidos se han visto eclipsados. Aquí nos interesan especialmente esas otras lecturas semánticas de lo espacial, ya que en la obra que estudiamos se ponen de manifiesto de manera especialmente significativa. En este sentido, es fundamental el valor de lo espacial cuando marca contrastes entre lo propio y lo ajeno; un personaje en un espacio desconocido se convierte muchas veces en marginal, en un visitante u observador condenado a ver las cosas desde fuera. El espacio también puede ser el elemento material y tangible que objetiva el mundo interior del personaje, es decir, puede convertirse en el reflejo de los estados anímicos de las criaturas que pueblan la 
narración (no olvidemos que esta visión del espacio bebe del ideario estético del Romanticismo). Finalmente el espacio puede adquirir en el texto una serie de valores simbólicos que el narrador puede codificar de distintas maneras: el arsenal metafórico que se puede activar es enormemente numeroso y variado, hasta el punto de que el espacio y su aprehensión pueden suponer un aprendizaje vital, un territorio fronterizo que el personaje sobrepasa simbólicamente, o un contraste distanciador entre el individuo y el resto del mundo. Como veremos, todo este potencial semántico del territorio se pone en juego en la dicotomía entre Europa (elemento real, urbano, tangible) y América (evocación ilusoria, nostálgica) que García Márquez dibuja en doce ocasiones en este libro. En primer lugar, los personajes del colombiano parten en estas narraciones de un binomio espacial ya marcado desde el prólogo: son «los americanos en Europa», los extranjeros, los inmigrantes. Esta idea es la base de todas las historias aunque los parámetros argumentales varíen. En segundo lugar, el espacio europeo en los Doce cuentos peregrinos materializa los estados emocionales de los personajes, que tienden a anclarse en la tristeza y la melancolía; de ahí por ejemplo la presencia casi omnipresente de la lluvia en varios relatos o la imagen de la nieve sobre un París inclemente en la última historia. Por último, todos los personajes extraen un aprendizaje de sus vivencias urbanas europeas (en ocasiones, la moraleja será terrible y los protagonistas encallarán en la locura o la muerte; en otros casos, el espacio y su conocimiento supone rebasar un límite que proporciona conocimiento y un aprendizaje vital de valor inapreciable). Como vemos, García Márquez se propone emplear en estos relatos todas las posibilidades semánticas de la categoría espacial, rebasando ampliamente su tradicional definición como pasivo marco de la trama.

El proyecto del novelista de construir una fisonomía de la identidad americana a partir del espacio tiene su correlato ensayístico en la obra de Fernando Aínsa titulada Los buscadores de la utopía, donde indaga sobre la esencia de lo americano a partir de la construcción novelística del espacio, investigando cómo los autores hispanoamericanos han representado literariamente los espacios propios y ajenos ${ }^{2}$. Todo el estudio parte del descubrimiento de una constante en la narrativa continental: «la búsqueda de un 'centro',

2. Otros autores han trabajado el tema de la identidad latinoamericana a través de su literatura, como por ejemplo H. A. Murena en El pecado original de América que llega a una conclusión semejante a la de García Márquez; es preciso buscar lo originario en la diferencia, en lo que nos hace distintos: «América debía descender a lo informe, a sus zonas abismales: únicamente cuando pareciera hallarse en pleno extravío se encontraría cerca de su camino. Porque aunque lo que los americanos buscábamos fuera igual que lo que ya habían logrado otros, debíamos buscarlo a través de la diferencia. Sólo separándonos de los demás llegaríamos a donde los demás estaban» (Murena, 1965: 10-11). 
la aspiración a construir un 'templo' a partir del cual la realidad y los demás tienden a ordenarse y a adquirir un sentido» (Aínsa, 1977: 32). Como lo americano carece de centros identitarios que le procuren una cohesión interna, es la literatura la que asume esta búsqueda incesante, y lo hace mediante dos procedimientos: el movimiento centrípeto (que dirige a los personajes hacia el interior del continente, sobre todo representado por el elemento natural y lo indómito) y el movimiento centrífugo, caracterizado como una evasión: «es la huida hacia afuera, intentando escapar al desajuste esencial del hombre americano asumiendo otro destino» (148). Según Aínsa, el personaje que mejor ha encarnado el movimiento centrífugo es Horacio Oliveira en Rayuela, la obra maestra de Julio Cortázar (147). Europa encarnará para muchos protagonistas novelescos latinoamericanos el nuevo lugar de peregrinación laica al que acudir para buscar una posible salvación personal; con esto, el mito de El Dorado «se invierte: en lugar del movimiento centrípeto, el centrífugo; en lugar del corazón de la selva, el cosmopolitismo de París» (Ibid.:149). Pero esta escapada hacia lo urbano nunca es la solución para los personajes: «Las grandes ciudades-de la que París es la Meca- son ya un elemento de aniquilación del 'yo' aterido que busca una identidad en su seno» (149-150). El Dorado «europeo» termina siendo al cabo como el americano, un engaño, una quimera que obliga a sus perseguidores a enfrentarse a sí mismos. De ahí que, en muchas ocasiones, nos encontraremos con un camino de ida y vuelta que llevará de nuevo a los protagonistas a Hispanoamérica; esto es lo que ocurre tanto al final de Rayuela como en algunos de los Doce cuentos peregrinos. Aunque, como ya veremos, el regreso devuelve al personaje cambiado para siempre, marcado por los hechos vividos.

\section{SEMÁNTICA ESPACIAL Y TRAMA EN DOCE CUENTOS PEREGRINOS}

Como indica Luz Aurora Pimentel en su estudio El espacio en la ficción, «nombrar es conjurar», ya que «de todos los elementos lingüísticos que se reúnen para crear una ilusión de realidad, el nombre propio es quizás el de más alto valor referencial» (Pimentel, 2001: 29). De manera que nombrar una ciudad (cualquier ciudad) supone poner en funcionamiento un complejo discursivo que incluye informaciones procedentes de distintas fuentes (cartográficas, artísticas, sociales, literarias, etc.). El nombre propio de una ciudad activa en el lector una serie de significados previos que entrarán en juego en la narración independientemente de la voluntad del autor. Este deberá prever dicha carga semántica, bien para sacarle provecho, bien para modificarla si es necesario, pero sin olvidar en ningún momento que «la ciudad se convierte en lo que Greimas ha llamado 'un referente global imaginario'» (30) que todos 
compartimos. Una ciudad literaria nunca está vacía de significado, nunca es neutra: al nombrarla, junto al poder denotativo propio del topónimo, se abre un potencial connotativo que debe ser manejado con prudencia. En los Doce cuentos peregrinos García Márquez es consciente de lo que supone nombrar Roma, Barcelona o París, y a veces se doblega a la visión tradicional de estas ciudades (lo podemos ver en la imagen que nos transmite de la capital italiana en «La santa», llena de turistas, motos y un calor chisporroteante); en otras ocasiones hace un consciente esfuerzo por mostrarnos otra cara de la ciudad, como por ejemplo cuando construye ese París anti-mítico de «El rastro de tu sangre en la nieve» o la Barcelona pre-fúnebre de «María dos Prazeres». Para lograr poner en funcionamiento ese complejo (y a veces contradictorio) núcleo semántico que es el espacio en los doce relatos, García Márquez hace uso de una red isotópica de rasgos caracterizadores concretos vinculados a lo espacial. Estas características terminan constituyendo el tono uniforme que subyace a las distintas historias y las hace ser percibidas como partes de un todo. Aislando y ejemplificando cada uno de estos valores asociados a lo geográfico (en particular a lo urbano ${ }^{3}$ ) nos será posible lograr un mayor acercamiento a la imagen espacial que el autor pretende transmitirnos. Podemos establecer un total de siete valores semánticos ligados a la espacialidad en Doce cuentos peregrinos; en las siguientes páginas los iremos analizando uno a uno, viendo de qué manera toman cuerpo en los distintos relatos estudiados. Estos tópicos de lectura espacial son los siguientes: la espacialidad en tránsito, la superstición, la presencia espacial de la muerte, el concepto del viaje religioso, la infancia feliz, la creación de una topografía kafkiana y la aparición de lo maravilloso o sobrenatural.

El primer rasgo fundamental, presente en todas las historias, es la creación de una espacialidad en tránsito, de manera que la itinerancia se convierte en el valor constante que comparten todos los personajes en su periplo europeo. Las criaturas que aparecen por estas páginas están casi siempre de paso por el viejo continente; bien de vacaciones, con propósitos religiosos, por motivos de salud o debido a razones laborales, su situación es casi siempre temporal y el punto de referencia es lo americano, que se evoca continuamente en los relatos a través de retrospecciones narrativas o descripciones. En otros cuentos, los personajes se nos presentan más asentados en determinadas ciudades europeas, pero su anclaje emocional sigue estando vinculado al espacio americano mediante los mecanismos de la añoranza o la nostalgia. Por

3. Hay sólo dos relatos en los que el ambiente europeo reflejado es escasamente urbano: se trata de «Espantos de agosto» y «El verano feliz de la señora Forbes», donde el espacio está más vinculado con lo rural y lo natural. 
ejemplo, en «Buen viaje, señor presidente» ya el propio título hace alusión al movimiento, al trayecto; en esta historia un presidente exiliado y enfermo busca en Ginebra una cura a su enfermedad al tiempo que recuerda su casa en La Martinica, llena de luz y vida. La capital suiza ya no es la ciudad que él conoció en su juventud y que, como él, ha envejecido, pero entre la nostalgia y las oscuras premoniciones encuentra la ayuda del matrimonio formado por Homero Rey y Lázara Davis. Estos, si bien se acercan al principio buscando beneficio, terminan adoptándolo como «el hijo mayor» y ayudándole a regresar a su tranquilo exilio ${ }^{4}$. El personaje ilustra en esta entrañable historia uno de esos itinerarios de ida y vuelta que son tan comunes en los héroes literarios latinoamericanos. Los protagonistas de «Espantos de agosto», «El verano feliz de la señora Forbes» y «El rastro de tu sangre en la nieve» se encuentran de plácidas vacaciones por Europa, aunque su tiempo de ocio se verá empañado de otras preocupaciones. El viaje a Europa en «Me alquilo para soñar» o «Tramontana» se debe a la imperiosa necesidad de ganarse la vida fuera de la tierra de origen. Por contraste con esta actitud de peregrinaje, encontramos en «María Dos Prazeres» a un personaje mucho más asentado en este lado del Atlántico (lleva más de cincuenta años en Cataluña), pero el constante recuerdo de su tierra y su condición de extranjera son evidentes en cada punto de la narración: en su «catalán perfecto» pervivía «la música de su portugués olvidado» y a un empleado de la agencia funeraria que la visita le pareció «una loca fugitiva de las Américas» (García Márquez, 1992: 138). Algo parecido le ocurre a Frau Frida en «Me alquilo para soñar» ya que, a pesar de vivir desde hace muchos años en Viena, compra en la costa portuguesa una casa «como un castillo falso sobre una colina desde donde se veía todo el océano hasta las Américas» (99). «El avión de la bella durmiente» sucede en un espacio en tránsito por excelencia: un aeropuerto, en concreto el Charles de Gaulle de París, donde el protagonista ve a una mujer de belleza extraordinaria, una «criatura de fábula» (85) que azarosamente ocupa un puesto contiguo al suyo durante el largo vuelo que comparten. Ella toma unas pastillas para dormir cuyo efecto dura todo el trayecto, mientras que el narrador, ensimismado, la mira e imagina una imposible historia de amor que finaliza cuando aterrizan en la impersonal y cruel «amazonia de Nueva York» (89), epítome de la ciudad moderna que cercena toda posibilidad de acercamiento humano.

4. La trama de este relato, en el que se invierten los conceptos de benefactor y beneficiario, ha llevado a José Manuel Camacho Delgado a establecer el paralelismo entre esta historia y la célebre novela picaresca El Lazarillo de Tormes, en su artículo «De Tormes a Aracataca: una interpretación de 'Buen Viaje Señor Presidente'», (Revista de Estudios Colombianos, $\mathrm{n}^{\circ} 17$, pp.10-13). 
La segunda característica común más destacable en los relatos es la superstición, la creencia en lo arcano o sibilino que comparten muchos de los personajes y que contrasta con un entorno europeísta amante de lo racional que desprecia o ignora estos conocimientos. En el ya citado «Buen viaje, señor presidente» el protagonista, enterado de la gravedad de su estado de salud, pide un café, proscrito durante tanto tiempo de su dieta de enfermo, sobre todo para poder leer en los posos las claves de su destino. Ya recuperado, en la carta que envía más tarde a sus benefactores desde La Martinica, les informa de que va a tomar las riendas de un movimiento político renovador y que ha abandonado el hábito de leer el fondo de la taza porque «sus pronósticos le resultaban al revés» (55). La protagonista de «Me alquilo para soñar», Frau Frida, es una colombiana afincada en la capital austríaca que posee el extraño don de los sueños premonitorios. Consigue con habilidad sacar provecho de su talento, pero el destino la lleva años más tarde a morir en un accidente automovilístico tras un golpe de mar en La Habana. Al final del relato, el narrador confiesa su creencia de que «sus sueños no eran más que una artimaña para vivir» (99) pero obedece a su recomendación de abandonar Viena una noche y no regresar en cinco años; es más, decide no volver jamás a la ciudad con la conciencia de considerarse «sobreviviente de un desastre que nunca conocí» (97). Frau Frida, que tanto había hecho por los destinos de otros, nada puede hacer por el suyo, pero en «Diecisiete ingleses envenenados» la superstición y la desconfianza salvan a Plácida Linero de una muerte segura y terriblemente ridícula. Cuando la mujer llega al puerto de Nápoles procedente de Riohacha, percibe la ciudad como un caos insolidario y estridente, un territorio infernal donde «hasta Dios se va de vacaciones en agosto» (164). El taxista la lleva a un lugar «decente» donde descansar hasta que el cónsul pueda atenderla: «un vetusto edificio de nueve pisos restaurados, en cada uno de los cuales había un hotel diferente» (165). El hotel recomendado está en la tercera planta, y todo parece perfecto excepto por un detalle que a la señora Linero «le encogió el corazón»: «Un grupo de turistas ingleses de pantalones cortos y sandalias de playa dormitaban en una larga fila de poltronas de espera. Eran diecisiete, y estaban sentados en un orden simétrico, como si fueran uno solo muchas veces repetido en una galería de espejos» (166). Prudencia Linero da un paso atrás y pide al ascensorista que la lleve a otro hotel, aunque es advertida de que ese es el único que dispone de comedor propio. Ya instalada en otro piso y repuesta de la impresión, Plácida Linero es conducida a una fonda para la cena, donde el plato del día son pajaritos cantores, hecho que a ella le parece una aberración («Para mí-dijo- sería como comerme a un hijo»). Al volver a su alojamiento se pierde entre las callejuelas con la sensación de estar 
«atravesando el infierno» (173) y cuando finalmente llega a orientarse descubre que el edificio está rodeado por ambulancias y carabineros: allí estaban los diecisiete ingleses, muertos por envenenamiento en el hotel contiguo al suyo y que ella había descartado por la mala impresión que le dieron sus rodillas rosáceas de turistas y su semejanza clónica. Convencida de que se encuentra en un lugar «indeseable» (172), corre hacia su habitación y atranca la puerta con todos los muebles tratando de separarse lo más posible del «horror de aquel país donde ocurrían tantas cosas al mismo tiempo» (175).

En algunos de estos relatos los personajes vinculan uno o varios elementos del espacio a la idea de la muerte, como si determinados lugares se dejasen contagiar por un denso presentimiento de fatalidad. En ocasiones, estos presagios se cumplen, mientras que en otros la señal es mal entendida por el protagonista que se muestra incapaz de leer adecuadamente sus designios. «María dos Prazeres» es una digna prostituta ya entrada en años que vive modestamente en el barrio de Gràcia de Barcelona. «Acababa de cumplir setenta y seis años y estaba convencida de que se iba a morir antes de Navidad» (137), razón por la cual empieza a preparar con todo esmero los trámites de su entierro. Un hecho de la infancia determina su obsesión por el lugar concreto de su sepultura; un desbordamiento del Amazonas la había convertido en testigo de un espectáculo lúgubre: «había visto los ataúdes rotos flotando en el patio de su casa con pedazos de trapos y cabellos de muertos en las grietas» (139). Por ello, María dos Prazeres sólo pone una condición al joven inexperto de la funeraria: «Quiero un lugar donde nunca lleguen las aguas» (139). El único sitio donde esto es posible es en el cementerio de Montjuich, en la parte alta de la ciudad, en concreto al lado de donde yace Durruti en una tumba sin nombre (elemento espacial que se llena de significado temporal al aludir de forma directa a la España del franquismo). Enseña a su perro a llegar solo a la que será su sepultura y así la solitaria mujer «superó el terror de no tener a nadie que llorara sobre su tumba». Empieza a percibir que la ciudad le envía mensajes proféticos y oscuros: «los susurros de los hombres que por primera vez en muchos años no hablaban de fútbol, los hondos silencios de los lisiados de guerra que les echaban migajas de pan a las palomas, y en todas partes encontró señales inequívocas de la muerte» (148). Recuerda que sólo se había sentido así de niña, en Manaos, al escuchar el silencio grávido de la selva un poco antes del amanecer. Una tarde la sorprende una fuerte tormenta al salir del camposanto y se ve sola y abandonada a su suerte hasta que un joven le ofrece llevarla a casa en un lujoso coche prestado. Antes de que ella salga del vehículo, el muchacho la mira con deseo y le pregunta si puede subir con ella; ante el asombro de María, el chico la sigue decidido pero asustado por la 
escalera. La llegada de esa relación sexual inesperada y revitalizadora era en realidad lo que María dos Prazeres había presentido tres años antes, pero no había sabido leer correctamente las señales. Justo en ese momento en el que se da cuenta de que no es la muerte lo que le espera (sino todo lo contrario) comprende que todo el dolor pasado ha valido la pena «aunque sólo hubiera sido para vivir aquel instante» (156).

En «Tramontana» los designios se cumplen y el fátum no yerra en sus pronósticos. El narrador nos sitúa de nuevo en Barcelona, en concreto en el cabaret de moda, el Boccacio, donde un joven caribeño es forzado a viajar a Cadaqués esa misma noche por un grupo de suecos ebrios y asalvajados. El muchacho ya había vivido en ese pintoresco pueblo catalán, hasta que llegó la tramontana y se vio derrotado por ella; escapó de Cadaqués convencido de que, si algún día volvía, moriría. Pero esta «era una certidumbre caribe que no podía ser entendida por una banda de nórdicos racionalistas, enardecidos por el verano y por los duros vinos catalanes» (180). El narrador, conocedor de primera mano del maleficio que el viento puede cargar sobre sus víctimas, se compadece del joven que fallecerá horas más tarde al saltar en marcha de la furgoneta que le llevaba hacia «una muerte ineluctable» (186).

El viaje religioso constituye el motivo de dos relatos fundamentales en el conjunto. Con fines espirituales llegaron a Europa los incansables peregrinos que protagonizan el ya comentado «Diecisiete ingleses envenenados» $\mathrm{y}$ «La santa». Plácida Linero había viajado a Italia tras la muerte de su marido con el único objeto de ver al Papa y había advertido a sus hijos que iría sola y con el hábito franciscano, tal como había prometido. En «La santa» el paciente y resignado Margarito Duarte vaga por una Roma bellísima en el sopor de agosto, pero indiferente a sus súplicas. El hombre había llegado desde una pequeña aldea de los Andes colombianos con el cuerpecito incorrupto de su hija a cuestas, buscando del Vaticano un merecido reconocimiento de santidad que se hacía cada vez más esquivo. El narrador del relato lo reencuentra en Roma, veintidós años después de haberlo conocido, con su mismo ánimo incombustible y esperando lo que consideraba que era suyo; la niña, etérea y desprendiendo todavía el vaho tibio de las rosas con las que fue enterrada, yacía en la cajita que muchos despistados confundían con la funda de un violonchelo. Mil impedimentos se habían puesto en contra de los deseos de Margarito Duarte, que seguía como un espectro atravesando las calles romanas, como «el único sobreviviente de una fauna extinguida», que veía cómo todo cambiaba a su alrededor incluyendo a la propia ciudad: «Nadie cantaba ni se moría de amor en las tractorías [sic] plastificadas de la Plaza de España. Pues la Roma de nuestras nostalgias era ya otra Roma antigua dentro de la antigua 
Roma de los Césares» (76). Su espera eterna lo convierte finalmente, a ojos del narrador, en el verdadero santo, en el digno merecedor de una canonización en toda regla.

Destacan en el conjunto dos relatos en los que el espacio europeo se utiliza como trasfondo de una infancia feliz, descrita desde el punto de vista de unos niños que pronto verán truncados sus deseos. Este mundo idílico aparece en «El verano feliz de la señora Forbes» y en «La luz es como el agua», aunque se trata de historias totalmente distintas por su tono y significado. La primera de ellas nos lleva a un ambiente natural y rural: la isla de Pantelaria en Sicilia, donde dos hermanos de Guacamayal pasan unas tranquilas y edénicas vacaciones ${ }^{5}$. Todo se tuerce cuando llega la institutriz alemana que su padre ha contratado, la señora Forbes, una «férrea y lánguida mujer otoñal» (192) que empieza a coartar las libertades de los niños: limita sus horas de baño con Oreste (el joven nativo que les enseña natación submarina), les hace leer a Shakespeare y masticar la comida diez veces con cada carrillo, hasta el punto de que para ellos «era imposible concebir un tormento más cruel que aquella vida de príncipes» (197). Los chicos, molestos por el doble rasero de la institutriz (que les exige protocolo al tiempo que ella empieza a beber por las noches, ver películas prohibidas y recitar poemas desgarradores) deciden actuar y planean envenenarla con un vino mortal. A la mañana siguiente de la emboscada encuentran la casa rodeada de ambulancias y militares y el cuerpo escuálido de la mujer tirado en el suelo de su cuarto, desnudo y cosido a puñaladas: «Eran veintisiete heridas de muerte, y por la cantidad y la sevicia se notaba que habían sido asestadas con la furia de un amor sin sosiego, y que la señora Forbes las había recibido con la misma pasión» (205-206). Entonces los hermanos descubren que el poder férreo contra el que habían querido luchar estaba quebrado en origen; algo en aquella «sargenta de Dortmund, empeñada en inculcarnos a la fuerza los hábitos más rancios de la sociedad europea» (196) se había dejado llevar por un instinto brutal e impropio de ella que la había arrasado. El personaje de la institutriz tiene un valor simbólico en el relato: ella representa lo europeo, la civilización y sus normas inflexibles que vienen a amenazar la paz idílica de los niños en aquel espacio de magia. El trágico fin de sus días es el precio que paga por su «traición» al orden establecido, «el precio inexorable de su verano feliz» (206).

5. La descripción (sobre todo durante la primera parte del relato) de una naturaleza espléndida y generosa, objeto de la diversión y el descubrimiento infantil, nos recuerda al tono empleado por Gerald Durrell en Mi familia y otros animales (Madrid, Alianza Editorial, 2008 [ $1^{a}$ ed. 1975]), novela de aprendizaje inspirada en la temporada que el autor pasó con su familia en la isla de Corfú. 
En «La luz es como el agua» nos reinstalamos en un paisaje urbano: concretamente un quinto piso en el número 47 del Paseo de la Castellana de Madrid. Allí viven «apretujados» dos hermanos, Totó y Joel, de nueve y siete años respectivamente. Desde su confinación urbana añoran la casa que poseían en la idílica Cartagena de Indias, donde disfrutaban de un muelle sobre la bahía en el que había espacio para dos barcos ${ }^{6}$. Obsesionados por lo marítimo, piden a sus padres como recompensa por sus buenas calificaciones escolares un bote de remos y una brújula, artilugios en principio totalmente innecesarios en un piso urbano. Lo que nadie sabe es que un día los niños consiguen romper una bombilla y «un chorro de luz dorada y fresca como el agua empezó a salir (...) y lo dejaron correr hasta que el nivel llegó a cuatro palmos. Entonces cortaron la corriente, sacaron el bote, y navegaron a placer por entre las islas de la casa» (210). Más tarde piden un equipo de submarinismo y, gracias a sus méritos escolares, consiguen el regalo. Para estrenarlo invitan a sus treinta y siete compañeros de clase, que fallecen con ellos cuando la luz se sale del cauce e inunda totalmente la casa. Es un bello relato que nos lleva al fantástico mundo de la infancia, donde todo, incluso lo terrible, es posible gracias al poder de la sugestión. Los niños desafían el espacio hostil y plano en el que se ven forzados a vivir; sin resignarse al prosaísmo de un piso de una céntrica calle madrileña, construyen con el poder de su imaginación otra realidad que termina siendo letal para ellos. Pero el relato finalmente les da una victoria póstuma, ya que tras su gesta alcanzan un poder oculto del que los demás están privados allí, «en Madrid de España, una ciudad remota de veranos ardientes y vientos helados, sin mar ni río, y cuyos aborígenes de tierra firme nunca fueron maestros en la ciencia de navegar en la luz» (213).

Un rasgo con el que Márquez caracteriza el espacio en estos relatos es la configuración de una topografía kafkiana. Entendemos por espacialidad kafkiana aquella que muestra una fisonomía engañosa al individuo, de manera que este no encuentra la manera de defenderse u ocultarse de una presencia hostil que nunca se conoce de primera mano. Denominamos también kafkiano al sistema que privilegia al documento sobre el hombre, de manera

6. Según Gastón Bachelard, la importancia del primer hogar es vital ya que siempre pervivirá en nosotros su imagen mítica, onírica, y su relación con el mundo fantástico de la niñez: «Cuando vuelven, en la nueva casa, los recuerdos de las antiguas moradas, vamos al país de la Infancia Inmóvil, inmóvil como lo Inmemorial. Nos reconfortamos viviendo recuerdos de protección (...). Porque los recuerdos de las antiguas moradas se reviven como ensueños, las moradas del pasado son en nosotros imperecederas» (La poética del espacio, México, Fondo de Cultura Económica, 2010, p. 36). 
que este último se ve envuelto en una red burocrática sin fin que termina por aniquilarlo. Es kafkiana la Roma que aparece reflejada en «La santa», ya que Margarito Duarte «espera» pacientemente la respuesta que debe llegar del Vaticano, pero que nunca llega; de la misma manera el agrimensor K. espera en El castillo a que alguien le rescate de ese laberinto que es la ciudad donde el tiempo va consumiéndose. La burocracia vaticana en el relato de Márquez tiene un papel análogo al de todos los elementos que dilatan la acción del personaje en El castillo y El proceso. Hay algo latente que no termina de manifestarse, que otros complotan para ocultar, un espacio sagrado que está vedado al individuo de a pie. Kafkiana es también la historia que lleva por título «Sólo vine a hablar por teléfono» en la que la joven mexicana $\mathrm{M}^{a}$ de la Luz Cervantes viaja sola hacia su casa de Barcelona cuando su coche se avería en el desierto de los Monegros. Allí es auxiliada por el conductor de un autobús lleno de mujeres que parecían aletargadas y que «se movían como en el fondo de un acuario» (109). Llega a un edificio donde nadie atiende su súplica de llamar por teléfono a su marido, Saturno el Mago, que en Barcelona ya va resignándose a la idea de que ella lo ha vuelto a abandonar. La joven lucha al principio por salir del psiquiátrico donde está recluida por error, pero al localizar al marido y ver la actitud de él, que asume mansamente que está enferma y no pone en duda la versión oficial de los médicos, decide dejarse llevar y permanecer allí. Mientras, Saturno, el mago sin imaginación, tras fracasados intentos de volver a verla, vuelve a América sin ella. El aparato burocrático del sanatorio mental donde es recluida la protagonista es un sistema imperfecto y arbitrario, propio de una sociedad autoritaria, vetusta, y sin un ápice de humanidad; es decir, "en el crepúsculo del franquismo» (115). Y kafkiana es también la ciudad de París en «El rastro de tu sangre en la nieve», historia de amor itinerante en la que una pareja de recién casados se disponen a pasar una larga luna de miel en Europa cuando se ven afectados por un hecho en apariencia intrascendente: la joven esposa, Nena Daconte, se pincha el dedo con una rosa y la pequeña herida no deja de sangrar. En París buscan un hospital y la joven ingresa mientras su inexperto marido, Billy Sánchez, queda a la deriva en urgencias sin saber qué hacer. Busca un hotel de mala muerte cercano al hospital, y allí ve extenderse las horas ilimitadamente, sin ropa (porque ella tenía las llaves de la maleta), sin nadie a quien hablar (porque nadie entiende español) y sobre todo «tan ofuscado y solo que no podía entender cómo pudo vivir alguna vez sin el amparo de Nena Daconte» (235). Todo allí se torna odiseico: «Nunca entendió el misterio de la luz de la escalera que se apagaba antes de que él llegara a su piso, ni descubrió la manera de volver a encenderla» (234). El tiempo se detiene y sigue un 
ritmo onírico basado en la repetición y el letargo: «cuando despertó eran las cinco en el reloj, pero no pudo deducir si eran las cinco de la tarde o del amanecer, ni de qué día de la semana ni en qué ciudad de vidrios azotados por el viento y la lluvia» (235). Después de visitar su embajada infructuosamente y sin tener nada que hacer excepto esperar, ve a lo lejos la torre Eiffel y decide acercarse hasta allí, "pero muy pronto se dio cuenta de que estaba más lejos de lo que parecía, y que además cambiaba de lugar a medida que la buscaba. Así que se puso a pensar en Nena Daconte sentado en un banco de la orilla del Sena» (240). Todos los elementos del espacio parecen confabularse en su contra y ello se suma (no de forma gratuita) a la ausencia de su joven esposa, verdadera «hada» del relato cuyo fatal destino le impide hacerse cargo del niño asustado que es Billy Sánchez.

En otras ocasiones, el espacio se convierte en el ámbito «realista» sobre el que los hechos maravillosos o sobrenaturales que les suceden a los latinoamericanos ejercen un fuerte contraste. Así, en «La santa», el cuerpo de la niña permanece incorrupto durante años y además carece de peso, propiedades mágicas que el padre de la criatura quiere emplear sin éxito para lograr su canonización. «Espantos de agosto» es un breve y curioso relato en el que el narrador cuenta sus breves vacaciones familiares en un castillo en Arezzo. Allí el anfitrión, Miguel Otero Silva, les cuenta la escabrosa leyenda fantasmal de Ludovico, señor de la Toscana, que en un arrebato había asesinado a su amada en el lecho. Lo que empieza siendo una anécdota para divertir a los niños se acaba cumpliendo a la mañana siguiente, cuando el narrador despierta en el dormitorio de Ludovico, con «las sábanas empapadas de sangre todavía caliente» (133) y su esposa al lado «navegando en el mar apacible de los inocentes» (132). En el último relato, «El rastro de tu sangre en la nieve», un hecho tan anodino como pincharse el dedo con una rosa provoca en la joven Nena Daconte una brutal hemorragia que la deja sin vida y sola en un solitario hospital de París, mientras su marido, desesperado, mata las horas a pocos metros de allí sin entender nada de lo que ocurre. En conclusión, en un espacio bello pero recto, medido, prosaico y en ocasiones anodino, coartado por la racionalidad sin límites de sus pobladores y donde suceden hechos que los esquemas racionalistas no alcanzan a explicar. Además, algo curioso subyace a los protagonistas de estas historias: son «latinoamericanos en Europa» a los que «les suceden cosas extrañas», como ya indicó el autor en el prólogo y precisamente de la conjunción de ambos elementos (la extrañeza de lo americano y lo europeo) surge el manantial irracional del que beben algunos de estos relatos. 


\section{«EL RASTRO DE TU SANGRE EN LA NIEVE»Y OTROS CUENTOS}

Volvemos al análisis de este último relato, sin duda el más bello del conjunto, y en el que García Márquez construye un versátil imaginario espacial caracterizado por una estética gélida e invernal, en la que los personajes van adentrándose como en una espiral que termina devolviéndonos una historia macabra.

La trágica historia de amor de dos jóvenes colombianos que viajan a Europa en su luna de miel es el argumento inicial. En el trayecto en coche desde Madrid a París, mientras Billy Sánchez conduce emocionado su carísimo regalo de bodas (un Bentley convertible), su mujer, la bella Nena Daconte, se desangra de forma absurda tras haberse pinchado accidentalmente el dedo con la espina de una rosa. En el periodo de tiempo que ambos comparten en el vehículo, rodeados por un paisaje nevado y solitario, (y mientras recorren sin detenerse la frontera con Francia, Hendaya, Bayona, Burdeos y Poitiers), el narrador hace uso de la retrospección para contarnos cómo se conocieron accidentalmente en Cartagena de Indias y cómo nació un amor irracional entre los jóvenes. Ambos eran los herederos de ricas familias de la élite provinciana, sin embargo, era mucho lo que los diferenciaba: Nena había sido educada en Europa, hablaba cuatro idiomas sin acento y tocaba magistralmente el saxofón tenor; Billy era un joven difícil, abandonado a la soledad por la perseverante indiferencia de sus padres y ocupaba su tiempo en meterse en problemas que soliviantaban a las autoridades. El día en que entra a la fuerza en los vestidores de mujeres del balneario y descubre desnuda a Nena Daconte, su vida cambia para siempre. Ella, asustada pero decidida, se dispone a «romper la cáscara amarga de Billy Sánchez», y lo consigue, cuando «debajo de la triste reputación de bruto que él tenía muy bien sustentada por la confluencia de dos apellidos ilustres, ella descubrió un huérfano asustado y tierno» (223). El verdadero protagonista del relato es Billy, ya que es él el que queda solo y desamparado cuando ingresan a Nena en un hospital de París y le impiden verla hasta varios días después. Es él quien debe aprender a moverse en un mundo que no entiende, que le resulta ilógico y donde la exclusividad de sus orígenes no le sirve para nada. El joven, que nunca había salido de su tierra, siente ya al poco de aterrizar en Madrid una punzada de desencanto: «la primera visión de una ciudad distinta de la suya, los bloques de casas cenicientas con las luces encendidas a pleno día, los árboles pelados, el mar distante» producen en él «un sentimiento de desamparo que se esforzaba por mantener al margen del corazón» (226). Al llegar a París queda solo en ese mundo distinto y hostil y todas esas vivencias constituyen un aprendizaje vital que termina convirtiéndole en adulto, cuestionando sus ideas preconcebidas y curtiéndolo 
en un mundo adverso en el que Nena Daconte era su guía, su brújula. Cuando el día de visita se presenta en el hospital, le comunican que ella murió tres días después del ingreso y que todo el país se había movilizado para buscarlo, mientras él agonizaba de amor a pocos metros de allí. París en el relato se ha convertido en un perverso laberinto, donde los trámites, el idioma, «las artimañas racionalistas (...) incomprensibles para un Sánchez de Ávila» (236) acaban por superar al personaje al sumirlo en el desamparo del extranjero en tierras lejanas.

En un artículo sobre Doce cuentos peregrinos, Carolina Sanabria relaciona este relato con dos conocidos cuentos infantiles: «Hansel y Gretel» y «La Bella Durmiente». Esta conexión es más que un parecido remoto y casual, ya que la historia que García Márquez escoge para cerrar su libro posee una serie de rasgos que aluden a su lectura como un cuento de hadas particular. En primer lugar y como ya hemos mencionado, es un relato de aprendizaje, en el que el personaje masculino tiene que valerse por sí mismo en un mundo ajeno al que ha sido arrojado involuntariamente. Ya el propio título del relato, «El rastro de tu sangre en la nieve», alude a la artimaña de los célebres personajes del cuento infantil de tirar migas de pan para no perder la pista del camino de regreso a casa. En su análisis de «Hansel y Gretel», Bruno Bettelheim parte de la base de que esta historia «encarna las ansiedades y tareas de aprendizaje del niño» (Bettelheim, 2010: 218) que debe superar su fase de dependencia, pero esto sólo es posible a partir de una experiencia traumática. El pequeño Hansel urde la estratagema de las migas de pan para evitar perderse en el denso bosque, es decir, intenta evitar el conflicto, dilatarlo; Billy Sánchez viaja al amparo de su mujer, ya experimentada en las lides del «mundo civilizado», pero cuando queda sin ella (que es la que media en otro idioma con los antipáticos guardias fronterizos y la que lo guía por el tráfico intenso de París hasta llegar al hospital) es lo más parecido a un náufrago. De esta manera, la ciudad de París se convierte en un denso bosque, en un espacio hostil que esconde todo tipo de peligros y amenazas. La joven esposa es el «hada benefactora» de su marido, es la que le ayuda a guiarse, la que conoce los oscuros secretos de esa espesura urbana ilógica que los tiene atrapados. A lo largo del relato, la figura de la joven siempre va asociada a su aspecto casi sobrenatural, envuelta en el delicado abrigo de visón que recibe como regalo de bodas de sus padres; el guardia francés que al principio se muestra hosco cambia de actitud al verla de cerca, cuando «se fijó con atención en la muchacha que se chupaba el dedo herido envuelta en el destello de los visones naturales y debió confundirla con una aparición mágica en aquella noche de espantos» (219). Nena Daconte es en todo el relato una «criatura de prodigio» (235), una «criatura radiante» 
(220) capaz de lidiar en esa ciudad laberíntica donde nada es lo que parece. Como «hada» de este relato, es la propia Nena Daconte la que da con la clave simbólica de toda la historia y establece asimismo su analogía con el cuento infantil:

El pinchazo era casi invisible. Sin embargo, tan pronto como regresaron al coche volvió a sangrar, de modo que Nena Daconte dejó el brazo colgando fuera de la ventana, convencida de que el aire glacial de las sementeras tenía virtudes de cauterio. Fue otro recurso vano, pero todavía no se alarmó. «Si alguien nos quiere encontrar será muy fácil», dijo con su encanto natural. «Sólo tendrá que seguir el rastro de mi sangre en la nieve». Luego pensó mejor en lo que había dicho, y su rostro floreció en las primeras luces del amanecer.

-Imagínate- dijo-: un rastro de sangre en la nieve desde Madrid hasta París. ¿No te parece bello para una canción? (229-230).

Otro relato con el que podemos establecer paralelismos semánticos destacables (gracias a la anécdota del pinchazo involuntario con terribles consecuencias) es «La Bella Durmiente», título al que el autor ya hace alusión en otro relato del libro, concretamente «El avión de la Bella Durmiente». Además de la evidente alusión al pinchazo desafortunado que provoca el maleficio, la imagen persistente de este cuento de hadas es la visión de la Bella Durmiente yaciendo en su sepulcro de cristal, en mitad de un bosque sepultado en los años y el olvido. «El rastro de tu sangre en la nieve» rescata una estética similar: «los padres de Nena Daconte (...) se llevaron el cuerpo embalsamado dentro del ataúd metálico, y quienes alcanzaron a verlo siguieron repitiendo durante muchos años que no habían visto nunca una mujer más hermosa, ni viva ni muerta» (García Márquez, 1992: 244). La imagen final del relato nos muestra al héroe solo saliendo del hospital, después de enterarse de que habían enterrado a su mujer a sólo doscientos metros del cuartucho de hotel donde a él lo consumían las horas y la desesperación. En ese momento, «ni siquiera se dio cuenta de que estaba cayendo del cielo una nieve sin rastros de sangre, cuyos copos tiernos y nítidos parecían plumitas de palomas, y que en las calles de París había un aire de fiesta, porque era la primera nevada grande en diez años» (244-245). La ciudad, ajena a su tragedia, celebra esa nieve nítida e inconsciente que a partir de ese momento Billy sólo relacionaría con la sangre de Nena Daconte y con el cuento de hadas gélido que acaba de protagonizar involuntariamente.

\section{CONCLUSIÓN}

Para cerrar este itinerario espacial por los cuentos de García Márquez, retomemos la condición de «peregrinos» que les da nombre. Si bien hemos 
comprobado que el autor aprovecha todo el potencial significativo de la categoría espacial en estas historias, lo mismo podemos decir del concepto de peregrinaje, ya que de todos los valores semánticos a los que el término alude es posible rastrear alguna pista en los relatos tratados. Es un peregrino alguien que anda por tierras extrañas, como son, sin excepción, los protagonistas de estas doce narraciones. También llamamos peregrino al que, por devoción religiosa, visita un lugar sagrado, como la impresionable Plácida Linero o Margarito Duarte en sus incansables y catastróficos periplos en pos de una prebenda sacra. También es peregrino algo insólito, extraño y poco común, dotado de una especial belleza, y sería imperdonable, desde el punto de vista estético, no celebrar estas doce historias desde el criterio de su peculiaridad, su originalidad y su inusual valor estético. Es también peregrino aquel que todavía puebla el mundo mortal, pero que se encamina a la vida eterna, definición que casa perfectamente con esa trascendencia que muchos de los personajes alcanzan al hallarse en esa encrucijada definitiva de sus vidas. Sin embargo, es un último significado del concepto el que nos resulta más curioso; peregrino es el nombre de un bello arbusto propio del Caribe (yuramira peregrina) que, durante todo el año, da pequeñas flores de un rojo brillante. Llegados a este punto, esto sólo puede traernos a la mente el nítido rastro de la sangre de Nena Daconte, radiante de belleza en su camino sin retorno hacia París.

\section{BIBLIOGRAFÍA}

AínSA, Fernando, 1977, Los buscadores de la utopía. La significación novelesca del espacio latinoamericano, Caracas, Monte Ávila Editores.

Alemany, Carmen, 1997, «Doce cuentos peregrinos: búsqueda fragmentaria de un nuevo modelo narrativo», en Túa Blesa (ed.), Quinientos años de soledad. Actas del congreso «Gabriel García Márquez», Zaragoza, Universidad de Zaragoza, pp. 347-351.

BACHelard, Gastón, 2010, La poética del espacio, México, Fondo de Cultura Económica, [ $1^{\text {a }}$ ed. español: 1965].

Bettelheim, Bruno, 2010, Psicoanálisis de los cuentos de hadas, Barcelona, Ares y Mares, [1 ${ }^{a}$ ed. español: 1977].

Camacho Delgado, José Manuel, 1997, «De Tormes a Aracataca: una interpretación de 'Buen viaje Señor Presidente'», Revista de Estudios Colombianos, pp.10-13.

Del Campo, Esteban, 1995, «La muerte en los Doce cuentos peregrinos», Cuadernos Hispanoamericanos, 539-40, pp. 281-282. 
DE NAVASCUÉS, Javier, 1997, «Espacio e identidad: Doce cuentos peregrinos», en Túa Blesa (ed.), Quinientos años de soledad. Actas del congreso «Gabriel García Márquez», Zaragoza, Universidad de Zaragoza, pp. 459-464.

DURRELl, Gerald, 2008, Mi familia y otros animales, Madrid, Alianza Editorial, [1 ${ }^{\text {a }}$ ed. 1975].

GARCía MÁrQUeZ, Gabriel, 2010, Yo no vengo a decir un discurso, Barcelona, Mondadori.

- 1992, Doce cuentos peregrinos, Barcelona, Mondadori.

IVAnOVICI, Víctor, 2008, Gabriel García Márquez y su Reino de Macondo, Madrid, SIAL Ediciones.

Murena, Héctor A., 1965, El pecado original de América, Buenos Aires, Editorial Sudamericana.

Palencia-Roth, Michael, 1997, «Los peregrinajes de Gabriel García Márquez o la vocación religiosa de la literatura», en Túa Blesa (ed.), Quinientos años de soledad. Actas del congreso «Gabriel García Márquez», Zaragoza, Universidad de Zaragoza, pp.81-90.

- 1983, Gabriel García Márquez: la línea, el círculo y las metamorfosis del mito, Madrid, Gredos.

Pimentel, Luz Aurora, 2001, El espacio en la ficción. La representación del espacio en los textos narrativos, México D.F., Siglo XXI Editores.

SANABRIA SING, Carolina, 2001, «¿Extraños peregrinos o extraño peregrinaje? Un acercamiento a los últimos cuentos de García Márquez», Revista de Filología y Lingüística de la Universidad de Costa Rica, 27(1).

SERNA, Mercedes, 1997, «La realidad novelada en Doce cuentos peregrinos de García Márquez», en Túa Blesa (ed.), Quinientos años de soledad. Actas del congreso «Gabriel García Márquez», Zaragoza, Universidad de Zaragoza, pp. 677-684.

VAnden Berghe, Kristine, 2009, «Los doce cuentos de Gabriel García Márquez. ¿O son trece? Paratopía, parodia e intertextualidad en Doce cuentos peregrinos», Bulletin of Spanish Studies, Vol. 86, nº 1, pp. 85-98.

Fecha de recepción: 18-12-2011

Fecha de aceptación: 30-5-2012

Anales, 24, 2012, pp. 369-389 